\title{
Evaluasi Kandungan Nutrisi, Tanin, dan Densitas Biji Asam (Tamarindus indica) Hasil Penggorengan sebagai Bahan Pakan Unggas
}

\section{Nutritional Content, Tannin, and Density of Tamarind Seeds (Tamarindus indica l.) Evaluation from Frying as a Poultry Feed}

\author{
E. A. Putra* dan O. Sjofjan \\ Fakultas Peternakan, Universitas Brawijaya, Malang 65145 - Indonesia \\ *Corresponding E-mail: ekoalpt@gmail.com \\ (Diterima: 22 November 2020; Disetujui: 7 Maret 2021)
}

\begin{abstract}
ABSTRAK
Biji asam memiliki nutrisi juga anti nutrisi dan nilai kerapatan jenis yang rendah. Oleh karena itu perlu proses pengolahan penggorengan dengan media yang berbeda. Tujuan penelitian ini yaitu untuk mengetahui pengaruh pengolahan bahan pakan biji asam terhadap kandungan nutrisi dan anti nutrisinya serta nilai kerapatan jenis sebagai bahan pakan alternative. Bahan yang digunakan dalam penelitian ini Biji asam utuh dan media penggorengan minyak dan pasir. Penelitian menggunakan rancangan acak lengkap terdiri dari 4 perlakuan dan 5 ulangan. Perlakuan P0: Biji asam (kontrol), P1: Biji asam dengan penggorengan minyak, P2: Biji asam dengan penggorengan sangrai, P3: Biji asam dengan penggorengan sangrai dengan pasir. Variabel penelitian adalah bahan kering, serat kasar, protein kasar, lemak kasar, kalsium, fosfor, gross energy, kandungan tanin dan kerapatan jenis. Data dianalisis dengan analisis varian dan uji lanjut Duncan. Hasil penelitian menunjukan dengan proses penggorengan memberikan pengaruh sangat nyata $(\mathrm{P}<0.01)$ terhadap bahan kering, protein kasar, serat kasar, lemak kasar, kalsium, fosfor, gross energy, kandungan tanin dan kerapatan jenis. Kesimpulannya penggorengan sangrai dengan media pasir menurunkan kandungan bahan kering, serat kasar, protein kasar, lemak kasar, kalsium, fosfor dan kandungan anti nutrisi tanin, namun meningkatkan kandungan gross energy dan nilai kerapatan jenis biji asam.
\end{abstract}

Kata kunci: densitas, kandungan zat makanan, penggorengan, tanin

\section{ABSTRACT}

Tamarind seeds have nutritional, anti-nutritional content and low-density value. Herefore it is necessary to process frying with different media. The purpose of this study was to determine the effect of processing tamarind seeds on nutritional and anti-nutritional content, as well as the density value as an alternative feed. The materials used in this Study were tamarind seed, a media frying oil, and sand. The treatments used were P0; tamarind seeds, P1: tamarind seed with oil frying, P2: tamarind seed with roasted frying, P3: tamarind seed with sand roasted frying. Variable include dry matter, crude protein, crude fiber, crude fat, calcium, phosphorus, gross energy, tannin total, and density. Data were analyzed using analysis of variance and Duncan's further tests. The results showed that the frying process had a very significant effect $(P<0.01)$ on dry matter. Crude fiber, crude protein, crude fat, calcium, phosphorus, gross energy, tannin total, and density. In conclusion, the roasted process with sand media reduces the dry matter content, crude fiber, crude protein, crude fat, calcium, phosphorus, and anti-nutritional content of tannins. Still, it increases the gross energy and density values of tamarind seeds.

Keywords: density, frying, nutritional content, tannin 


\section{PENDAHULUAN}

Pakan merupakan faktor penyumbang biaya terbesar dalam usaha peternakan khususnya unggas yang banyak dibudidayakan oleh peternak diindonesia. Biaya untuk pakan yang tinggi disebabkan adanya ketergantungan bahan pakan impor yang menyebabkan terjadinya fluktuatif harga pakan khususnya unggas. Biaya yang besar untuk menyediakan pakan unggas menyebabkan perlu adanya pemanfaatan bahan pakan hasil samping yang ada di masyarakat baik dari limbah dapur, perkebunan maupun pertanian Sjofjan et al. (2020). Pemanfaatan bahan pakan alternatif yang memiliki potensi nutrisi dan ketersediaan yang cukup yaitu biji asam.

Biji asam merupakan tanaman yang potensial sebagai bahan pakan dengan penyebaran biji asam yang yang berada didaerah Nusa Tenggara Timur. Menurut Data BPS Nusa Tenggara Timur (2017) bahwa produksi hasil hutan non kayu untuk biji asam sebesar 778.000 Ton/tahun. Biji asam memiliki kandungan protein kasar 23,19\%, lemak kasar 8,84\%, serat kasar $7,23 \%$, kandungan tannin 675,0 $\mathrm{mg} / 100 \mathrm{~g}$ bahan (Vadivel and Pugalenthi, 2010). Biji asam memiliki potensi nutrisi yang baik tetapi memiliki keterbatasan jika dimanfatakan sebagai bahan pakan alternatif akibat adanya kandungan anti nurisi seperti tanin.

Kandungan tanin menyebabkan pembentukan senyawa kompleks dengan ikatan peptide yang berasal dari protein, sehingga tidak dapat larut dalam saluran pencernaan dikeluarkan bersama feses yang akan mempengaruhi ketersediaan protein, perlu adanya pengolahan untuk mengurangi kandungan anti nutrisi biji asam. Tanin dapat mempengaruhi nilai nutrisi produk pakan dengan mengikat mineral dan mengurangi penyerapan mineral serta membentuk senyawa kompleks dengan protein sehingga menghambat pencernaan dan penyerapannya (Olawoye and Gbadamosi, 2017).

Cara yang dilakukan untuk mengurangi kandungan tanin perlu dilakukan proses pengolahan bahan dengan penggorengan. Metode kombinasi dengan penggorengan untuk menurunkan ANF (factor anti-nutrisi) yang lebih banyak digunakan untuk bahan pakan biji-bijian serta metode pengolahan dapat menekan biaya operasional bahan pakan dan meningkatkan kulaitas nilai gizinya serta menurunkan kandungan ANF (Yanuartono et al. 2019). Pengolahan bahan pakan menggunakan proses penggorengan juga mengakibatkan penurunan komposisi kimia dan zat makanan seperti kadar air yang dapat mempengaruhi kerapatan jenis bahan, kadar abu, kadar protein dan kadar lemak. Tinggi atau rendahnya penurunan akan kandungan nutrisi bahan pangan akibat penggorengan di pengaruhi oleh jenis bahan, media dan suhu penggorengan. Sehingga perlu dilakukan penelitian tentang pengolahan penggorengan dengan media yang tepat untuk menurunkan kandungan anti nutrisi juga untuk meningkatkan nilai kandungan nutrisi serta nilai kerapatan jenis bahan.

Berdasarkan permasalahan di atas, dilakukan penelitian yang bertujuan untuk mengetahui pengaruh pengolahan bahan pakan biji asam dengan media penggorengan yang berbeda seperti dengan penggorengan minyak, sangrai dan sangrai dengan pasir terhadap kandungan nutrisi dan anti nutrisinya serta nilai kerapatan jenis bahan.

\section{METODE}

\section{Waktu dan Tempat Penelitian}

Penelitian ini dilaksanakan pada April-Juni 2019 di Laboratorium Nutrisi dan Makanan Ternak Fakultas Peternakan Universitas Brawijaya Malang untuk analisis proksimat dan Laboratorium Kimia Fakultas Matematika dan Ilmu Pengetahuan Alam Universitas Brawijaya untuk uji total tanin.

\section{Alat dan Bahan}

Alat yang digunakan dalam penelitian ini yaitu timbangan digital kapasitas 3,0 $\mathrm{kg}$ dengan tingkat akurasi $0,2 \mathrm{~g}$, wadah 
penggorengan, kantong plastik zip, thermometer. Bahan yang digunakan yaitu Biji asam dari Desa Jungcang-cang, Pamekasan, Madura dan bahan media penggorengan pasir dan minyak goreng.

\section{Pelaksanaan Penelitian}

Pelaksanaan penelitian ini dimulai dengan mempersiapkan biji asam yang sudah dibersihkan dan dilakukan proses pengeringan. Sampel biji asam dibagi menjadi 4 kelompok dengan 5 ulangan sebanyak 2 kg. (P0) tanpa proses penggorengan sebagai kontrol, Selanjutnya dilakukan proses penggorengan dengan media penggorengan yang berbeda yaitu (P1) penggorengan dengan media minyak sampai biji asam terendam seluruhnya, (P2) penggorengan sangrai (tanpa penggunaan media pasir dan minyak) dan (P3) Penggorengan sangrai dengan media pasir sampai dengan suhu 100$110^{\circ} \mathrm{C}$ dengan waktu 10 menit. Media minyak dan pasir menggunakan perbandingan 1:5 (biji asam: media minyak/pasir). Kelompok Biji asam setiap perlakuan dilakukan proses penggilingan (grinding) dan disaring dengan ukuran 0,6-1 $\mathrm{mm}$.

Sampel masing-masing perlakuan yang telah dilakukan proses penggilingan selanjutnya dilakukan analisis uji proksimat yang terdiri dari (bahan kering, protein kasar, serat kasar, lemak kasar, kalsium, fosfor serta gross energy, dilakukan analisisi anti nutrisi untuk mengtahui total tanin serta kerapatan jenis biji asam.

\section{Peubah yang Diamati}

\section{Kandungan Nutrisi}

Kandungan zat makanan terdiri dari Bahan kering, Protein kasar, Serat kasar, Lemak kasar, Kalsium, Fosfor, gross energy bahan. Analisis proksimat kandungan zat makanan sesuai dengan prosedur AOAC (1990).

\section{Kandungan Anti Nutrisi}

Kandungan Anti nutrisi yaitu total tanin ditentukan dengan metode AOAC (1990).

\section{Nilai Densitas}

Kerapatan Jenis atau densitas ( $g / \mathrm{l})$ dihitung dengan cara membandingkan berat bahan $(\mathrm{g})$ dengan volume ruang $\left(\mathrm{cm}^{3}\right)($ Khalil, 1999).

\section{Rancangan Percobaan}

Percobaan ini menggunakan Rancangan Acak Lengkap dengan 4 perlakuan dan 5 Ulangan dengan Suhu $100-110^{\circ} \mathrm{C}$ selama 10 menit (Ly et al., 2017 dan Vadivel and Pugalenthi, 2010 yang termodifikasi) rincian:

P0 : Biji asam tanpa perlakuan (kontrol)

P1 : Biji asam penggorengan dengan media minyak

P2 : Biji asam penggorengan sangrai

P3 : Biji asam penggorengan sangrai dengan media pasir

Data penelitian dianalisis dengan analisis varians menggunakan Rancangan Acak Lengkap (RAL) dan uji lanjut Duncan's (Steel dan Torrie, 1989).

\section{HASIL DAN PEMBAHASAN}

\section{Pengaruh Proses Penggorengan dengan Media yang Berbeda terhadap Kandungan Nutrisi dan Anti Nutrisi Biji Asam}

Hasil penelitian menunjukkan bahwa perlakuan penggorengan yang berbeda berpengaruh sangat nyata $(\mathrm{P}<0,01)$ terhadap bahan kering (Tabel 1). Terjadinya penurunan kandungan bahan kering akibat perlakuan penggorengan yang berbeda. Nilai bahan kering mengalami penurunan pada setiap perlakuan akibat adanya proses pemanasan yang menyebabkan pengurangan kandungan air yang ada di dalam biji asam. Kandungan bahan kering akan mengalami penurunan akibat peningkatan perbandingan kandungan air pada bahan (Wea et al., 2020).

Kandungan protein kasar biji asam hasil penggorengan yang berbeda berdasarkan analisis menunjukan adanya perbedaan sangat nyata $(\mathrm{P}<0,01)$. Protein kasar mengalami penurunan pada setiap perlakuan dan penurunan yang signifikan terjadi pada 
Tabel 1. Kandungan Nutrisi dan Anti Nutrisi (Tanin) Biji Asam dengan Media Penggorengan Berbeda

\begin{tabular}{lcccc}
\hline \multirow{2}{*}{ Parameter } & \multicolumn{3}{c}{ Perlakuan } \\
\cline { 2 - 5 } & P0 & P1 & P2 & P3 \\
\hline Bahan Kering (\%) & $94,78 \pm 0,2^{\mathrm{C}}$ & $90,75 \pm 0,62^{\mathrm{A}}$ & $92,30 \pm 0,22^{\mathrm{B}}$ & $91,60 \pm 0,90^{\mathrm{A}}$ \\
Protein Kasar (\%) & $17,94 \pm 0,05^{\mathrm{C}}$ & $17,25 \pm 0,11^{\mathrm{A}}$ & $17,48 \pm 0,04^{\mathrm{B}}$ & $17,53 \pm 0,17^{\mathrm{B}}$ \\
Lemak Kasar (\%) & $7,38 \pm 0,02^{\mathrm{C}}$ & $7,52 \pm 0,05^{\mathrm{D}}$ & $6,69 \pm 0,02^{\mathrm{B}}$ & $6,30 \pm 0,06^{\mathrm{A}}$ \\
Serat Kasar (\%) & $5,17 \pm 0,04^{\mathrm{D}}$ & $4,79 \pm 0,05^{\mathrm{C}}$ & $2,30 \pm 0,08^{\mathrm{A}}$ & $3,66 \pm 0,04^{\mathrm{B}}$ \\
Kalsium (\%) & $1,19 \pm 0,02^{\mathrm{D}}$ & $1,01 \pm 0,03^{\mathrm{B}}$ & $1,08 \pm 0,02^{\mathrm{C}}$ & $0,80 \pm 0,01^{\mathrm{A}}$ \\
Fosfor (\%) & $0,33 \pm 0,02^{\mathrm{B}}$ & $0,30 \pm 0,03^{\mathrm{AB}}$ & $0,31 \pm 0,01^{\mathrm{B}}$ & $0,27 \pm 0,01^{\mathrm{A}}$ \\
Gross energy (kkal/kg) & $4418,84 \pm 11,55^{\mathrm{A}}$ & $4537,70 \pm 31,00^{\mathrm{C}}$ & $4462,76 \pm 10,36^{\mathrm{AB}}$ & $4476,40^{\mathrm{B}} \pm 43,82$ \\
Total tanin (\%) & $0,41 \pm 0,02^{\mathrm{C}}$ & $0,30 \pm 0,04^{\mathrm{AB}}$ & $0,34 \pm 0,02^{\mathrm{B}}$ & $0,26 \pm 0,03^{\mathrm{A}}$ \\
\hline
\end{tabular}

Keterangan: $\mathrm{P} 0=$ Biji asam tanpa perlakuan (kontrol), $\mathrm{P} 1$ = Biji asam penggorengan dengan media minyak, $\mathrm{P} 2$ $=$ Biji asam penggorengan sangrai, $\mathrm{P} 3=\mathrm{Biji}$ asam penggorengan sangrai dengan media pasir. Huruf Superscript $^{\mathrm{A}-\mathrm{D}}$ pada baris yang sama menunjukkan hasil yang sangat berbeda nyata $(\mathrm{P}<0,01)$.

perlakuan penggorengan sangrai sebesar $0,69 \%$ (Tabel 1). Kandungan protein biji asam yang menurun pada setiap perlakuan akibat pengaruh pemanasan menyebabkan terjadinya perubahan struktur protein pada biji asam. Hal tersebut disebabkan pengaruh suhu pemanasan yang merubah struktur protein pada bahan. Penelitian Sundari et al. (2015) menjelaskan bahwa proses penggorengan didapatkan kadar protein yang terendah dari semua pengolahan, hal ini dikarenakan pengaruh suhu yang digunakan mengakibatkan terjadinya kerusakan protein akibat suhu yang tinggi. Semakin tinggi suhu mengakibatkan penurunan kandungan protein bahan.

Kandungan lemak kasar menunjukkan adanya hasil yang berbeda sangat nyata $(\mathrm{P}<0,01)$ (Tabel 1). Kandungan lemak kasar mengalami penurunan pada perlakuan sangrai dan pasir akibat adanya penyerapan minyak ke dalam pasir saat proses penggorengan sehingga tidak adanya penyerapan kandungan minyak ke bahan. Peningkatan kandungan lemak terjadi pada perlakuan penggorengan dengan minyak sebesar $0,14 \%$ hal ini disebabkan karena adanya penyerapan media minyak ke dalam biji asam yang terjadi pada saat proses penggorengan. Putro et al. (2012) bahwa penurunan kadar air dalam bahan menyebabkan tingginya penyerapan minyak yang dihubungkan dengan kecenderungan penurunan kadar air, hal ini menunjukan adanya penyerapan minyak akibat penurunan kadar air pada ruang kosong bahan.

Kandungan serat kasar biji asam mengalami penurunan pada setiap perlakuan penggorengan memberikan pengaruh yang sangat nyata $(\mathrm{P}<0,01)$. Penurunan kandungan serat kasar yang signifikan pada penggorengan sangrai sebesar 2,87\%. Penurunan kandungan diakibatkan karena adanya kerusakan serat kasar dan pelunakan daging pada biji asam akibat hilangnya kulit pada biji saat proses pengolahan penggorengan. Menurut Agustina et al. (2013) bahwa pemanasan serat kasar akan menyebabkan terjadinya kerusakan serat sehingga kadar pati (karbohidrat) akan mengalami penurunan. Kandungan serat kasar pada biji asam yang tinggi bersifat bulky atau mengenyangkan yang menyebabkan kapasitas tembolok cepat penuh dan menyebabkan konsumsi ransum unggas terhenti. Menurut Amrullah (2003) serat kasar yang tinggi menyebabkan unggas akan merasa kenyang, sehingga dapat menurunkan konsumsi karena serat kasar bersifat voluminous.

Kandungan kalsium dan fosfor mengalami penurunan pada setiap perlakuan penggorengan memberikan pengaruh yang 
sangat nyata $(\mathrm{P}<0,01)$. Penurunan kandungan kalsium dan fosfor akibat adanya penguapan kandungan mineral yang ikut hilang pada saat penguapan air pada bahan. Hal ini juga terjadi pada penelitian Ersoy and Ozeren (2009) bahwa Pengolahan dengan suhu tinggi menyebabkan terjadinya penguapan air pada bahan akibat keluarnya molekul air dari permukaan bahan pangan seperti kandungan mineral yang ikut larut dengan air.

Energi potensial yang terkandung dalam suatu bahan, tetapi belum dapat dimanfaatkan langsung oleh ternak disebut gross energy. Kandungan gross energy mengalami peningkatan 43,92-118,6 Kkal/g. Peningkatan kandungan gross energy bahan dapat mempengaruhi energy metabolis pada unggas. Peningkatan kandungan gross energy terdapat pada hasil penelitian Ly et al. (2017) bahwa terjadinya peningkatan kandungan gross energy karena pengaruh dari proses pengolahan bahan. Semakin tinggi nilai protein dan lemak suatu bahan pakan maka gross energi-nya juga semakin tinggi.

Tanin merupakan antinutrisi yang memiliki kemampuan untuk mengikat protein. Senyawa tanin berpengaruh bagi ternak unggas karena menghambat pencernaan dan penyerapan nutrisi. Menurut Widodo (2005) bahwa kandungan tanin menghambat pertumbuhan unggas karena tanin dapat menekan nitrogen dan menurunkan daya cerna asam amino yang diserap vili-vili usus unutk dimanfaatkan untuk pertumbuhan dan perkembangan jaringan tubuh. Penurunan kandungan tanin terjadi akibat pengolahan penggorengan yang berbeda pada biji asam (Tabel 1). Penurunan kandungan tannin pada biji asam akibat perlakuan pemanasan terjadi pada penelitian Ly et al. (2017) pada dengan nilai $3620 \mathrm{mg} / 100 \mathrm{~g}$ menjadi $2760 \mathrm{mg} / 100 \mathrm{~g}$ pada perlakuan penggorengan kering. Menurut Handayani et al. (2016) bahwa proses termal yang dapat merusak senyawa antioksidan seperti senyawa bioaktif dan antioksidan seperti tanin, flavonoid, polifenol dan saponin.

Tanin memiliki sifat yang membentuk senyawa komplek peptida dari protein sehingga tidak dapat dicerna dalam saluran pencernaan dan mempengaruhi ketersediaan nutrisi. Penurunan kandungan tanin pada biji asam akan berdampak baik pada pemanfaatan biji asam sebagai bahan pakan alternatif seperti unggas karena tanin tidak akan mampu mengikat protein dan enzim pencernaan untuk membentuk senyawa kompleks yang sehingga bahan pakan akan mudah dicerna dan menyebabkan palatabilitas meningkat.

\section{Pengaruh Proses Penggorengan dengan Media yang Berbeda terhadap Densitas Biji Asam}

Densitas merupakan perbandingan berat suatau bahan dengan volume ruangan. Densitas diukur dengan menimbang bahan pakan ke dalam suatu volume ruangan. Nilai densitas menunjukan hasil yang sangat berbeda nyata $(\mathrm{P}<0,01)$ (Tabel 2$)$.

Hasil tersebut menunjukkan bahwa nilai densitas di pengaruhi oleh kadar air yang terdapat dalam bahan, apabila kandungan kadar air dalam bahan tinggi dapat menyebabkan pakan mengembang sehingga menurunkan nilai densitas bahan. Perlakuan P0 memiliki kadar air yang tinggi dibandingankan perlakuan lainnya karena tidak adanya proses perlakuan pengolahan. Hal ini sesuai dengan pendapat Rahmana et al. (2016) yang menyatakan bahwa semakin tinggi kadar air bahan pakan akan berpengaruh terhadap kerapata jenis bahan (density), nilai densitas dipengaruhi oleh tinggi rendahnya kadar air pada bahan yang dapat mempengaruhi volume ruangan penyimpanan. Pengukuran nilai densitas dilakukan untuk mengetahui berapa banyak jumlah bahan dalam 1 liter volume ruangan. Khalil (1999) menyatakan bahwa proses pengukuran kerapatan jenis berdasarkan perbandingan antara berat suatu bahan yang digunakan dengan volume ruang bahan yang ditempati.

Nilai Densitas (bulkdensity) merupakan salah satu parameter yang digunakan untuk merencanakan penyimpanan bahan pakan, volume alat pengolahan, jenis pengemasan 
Tabel 2. Nilai Densitas Biji Asam dengan Media Penggorengan Berbeda

\begin{tabular}{ll}
\hline Perlakuan & Densitas $(\mathrm{g} / \mathrm{l})$ \\
\hline P0 & $448,42 \pm 5,22^{\mathrm{A}}$ \\
P1 & $612,13 \pm 4,64^{\mathrm{B}}$ \\
P2 & $633,10 \pm 5,17^{\mathrm{C}}$ \\
P3 & $687,37 \pm 5,24^{\mathrm{D}}$ \\
\hline
\end{tabular}

Keterangan: $\mathrm{P} 0=$ Biji asam tanpa perlakuan (kontrol), $\mathrm{P} 1=$ Biji asam penggorengan dengan media minyak, $\mathrm{P} 2$ = Biji asam penggorengan sangrai, $\mathrm{P} 3=\mathrm{Biji}$ asam penggorengan sangrai dengan media pasir. Huruf Superscript $^{\mathrm{A}-\mathrm{D}}$ pada baris yang sama menunjukkan hasil yang sangat berbeda nyata $(\mathrm{P}<0,01)$.

atau sarana transportasi. Menurut Jaelani et al. (2016), kerapatan pemadatan tumpukan dan kerapatan tumpukan mempunyai hubungan sangat erat dan sangat berperan terhadap penentuan kapasitas silo dan pencampuran bahan.

\section{KESIMPULAN}

Proses penggorengan dengan media yang berbeda menurunkan kandungan bahan kering, serat kasar, protein kasar, kalsium, fosfor, dan kandungan anti nutrisi tannin, namun meningkatkan kandungan lemak kasar, gross energy dan nilai kerapatan jenis biji asam serta perlakuan terbaik adalah Penggorengan sangrai dengan media pasir.

\section{DAFTAR PUSTAKA}

Agustina, N., W. Sri., Warji, dan Tamrin. 2013. Pengaruh suhu perendaman terhadap koefisien difusi dan sifat fisik kacang merah. Jurnal Teknik Pertanian Lampung. 2(1): 35-42.

Amrullah, I. K. 2003. Nutrisi Ayam Petelur. Lembaga Satu Gunung Budi, Bogor.

AOAC. 1990. "Official method of Analysis" $15^{\text {th }}$ edition, Association of official Analytical. Chemists, Washington DC.

Badan Pusat Statistik (BPS) Provinsi Nusa Tenggara Timur. 2017. Produksi Hasil Hutan Non kayu 2016. Badan Pusat Statistik Nusa Tenggara Timur.
Ersoy, B., A. Ozeren. 2009. The effect of cooking methods on mineral and vitamin contents of African catfish. Food Chemistry. 115(2): 419-422.

Handayani, H., F. H. Sriherfyna, dan Yunianta. 2016. Ekstraksi antioksidan daun sirsak metode ultrasonic bath (kajian rasio bahan: pelarut dan lama ekstraksi). Jurnal Pangan dan Agroindustri. 4(1): 262-267.

Jaelani, A., S. Dharmawati, dan Wacahyono. 2016. Pengaruh tumpukan dan lama masa simpan pakan pelet terhadap kualitas fisik. Ziraa'ah, 41(2): 261-268.

Khalil. 1999. Pengaruh kandungan air dan ukuran partikel terhadap kualitas fisik ransum lokal: sudut tumpukan, daya ambang, dan faktor higroskopis. Media Peternakan. 22(1): 33-42.

Ly, J., O. Sjofjan., I. H. Djunaidi, and Suyadi. 2017. Effect of processing methods on nutrient and tannin content of tamarind seeds. Tropical Drylands. 1(2): 78-82.

Olawoye, B. T. and S. O. Gbadamosi. 2017. Effect of different treatments on in vitro protein digestibility, antinutrients, antioxidant properties and mineral composition of Amaranthus viridis seed. Cogent Food \& Agriculture. 3: $1-14$.

Putro, J. S., I. W. Budiastra, dan U. Ahmad. 2012. Optimasi Proses Penggorengan Hampa dan Penyimpanan Keripik Ikan Pepetek (Leiognathus sp.). Jurnal Keteknikan Pertanian. 26(1): 25-32. 
Rahmana, I., D. A. Mucra, dan D. Febrina. 2016. Kualitas fisik pelet ayam broiler periode akhir dengan penambahan feses ternak dan bahan perekat yang berbeda. Jurnal peternakan. 13(1): 33 - 40.

Sjofjan, O., D. N. Adli, dan F. A. Muflikhien. 2020. Konsep bahan pakan pengganti bekatul dalam pakan itik hibrida dengan tepung bonggol pisang (Musa paradiciasa l.) terhadap peningkatan persentase karkas, organ dalam, dan lemak abdominal. Jurnal Nutrisi Ternak Tropis dan Ilmu Pakan. 2(2): 78-85.

Steel, R. G. D. and J. H. Torrie. 1989. Prinsip dan Prosedur Statistik.. PT Gramedia Pustaka Utama. Jakarta.

Sundari, D., Almasyhuri, dan A. Lamid. 2015. Pengaruh Proses Pemasakan Terhadap Komposisi Zat Gizi Bahan Pangan Sumber Protein. Media Litbangkes. 25(4): 235-242.
Vadivel,V. and M. Pugalenthi. 2010. Evaluation of nutritional value and protein quality of an under-utilized tribal food legume. Indian Journal of Tradisional Knowledge. 9(4): 791-797.

Wea, R., A. Y. Ninu, dan B. B. Koten. 2020. Kualitas nutrisi dan anti nutrisi pakan cair fermentasi berbahan biji asam. Jurnal Peternakan Indonesia. 22(2): 133-140.

Widodo, W. 2005. Tanaman Beracun dalam Kehidupan Ternak. Universitas Muhammadiyah Malang, Malang.

Yanuartono., A. Nururrozi., S. Indarjulianto., H. Purnamaningsih, dan S. Raharjo. 2019. Metode tradisional pengolahan bahan pakan untuk menurunkan kandungan faktor antinutrisi: review singkat. Jurnal Ilmu Ternak, 19(2): 97107. 